\title{
EVALUATION OF ALLELOPATHIC POTENTIAL OF LEAF EXTRACT OF KIELMEYERA CORIACEA ON LACTUCA SATIVA L
}

\author{
AVALIAÇÃO DO POTENCIAL ALELOPÁTICO DE EXTRATO DE FOLHAS DE \\ KIELMEYERA CORIÁCEA SOBRE LACTUCA SATIVA L
}

\author{
Valter Henrique Marinho dos SANTOS ${ }^{1}$; Gabriel Silva DANELUZZI ${ }^{2}$; \\ Luciana Pereira SILVA ${ }^{3}$; Regildo Márcio Gonçalves da SILVA \\ 1. Biólogo, doutorando no Programa de Pós-Graduação em Ciências Biológicas (Botânica), Universidade Estadual Paulista - UNESP, \\ Botucatu, SP, Brasil; 2. Biólogo, doutorando no Programa de Pós-Graduação em Fisiologia e Bioquímica de Plantas, Escola Superior de \\ Agricultura "Luiz de Queiroz" - ESALQ, Universidade de São Paulo - USP, Piracicaba, SP, Brasil; 3. Professora, Doutora, Fundação \\ Educacional do Município de Assis - FEMA, Assis, SP, Brasil; 4. Professor, Doutor, Faculdade de Ciências e Letras de Assis, \\ Laboratório de Fitoterápicos - UNESP, Assis, SP, Brasil. regildos@yahoo.com.br
}

\begin{abstract}
Kielmeyera coriacea Mart. (Clusiaceae), popularly known as "pau-santo", is a typical Brazilian cerrado tree known due to its varied secondary metabolites. This study aimed to determine the allelopathic potential of the hydroalcoholic extract of leaves of $K$. coriacea through bioassays of seed germination, seedling growth and mitotic index of Lactuca sativa L. (lettuce). In addition it was done the tetrazolium assay and a phytochemical screening. The extract concentrations caused alterations in germination parameters, in root growth and in the mitotic index. The phytochemical screening showed the presence of triterpenes, coumarins, steroids, flavonoids and condensed tannins, compounds known to confer allelopathic characteristics upon other species. These data indicate that $K$. coriacea presents an allelopathic potential because its leaf extracts interfere with germination and growth without any interference of $\mathrm{pH}$ and osmotic potential in the results.
\end{abstract}

KEYWORDS: Kielmeyera coriacea. Germination Parameters. Mitotic Index. Phytochemical Screening. Seedling Growth.

\section{INTRODUCTION}

Allelopathy is defined as the interference of plants in the growth and development of another (including microorganisms) through the release of chemical compounds into the environment (RICE, 1984). This interaction produces different answers, positive or negative, in plants sensitive to such substances, collectively known as allelochemicals, which are usually secondary plant products or waste products of main metabolic pathways (INDERJIT and NILSEN, 2003). According to Gottlieb (1982), allelochemicals are chemical signals transmitted in the environment, usually in small quantities, and account for multiple chemical interactions between different organisms.

These interactions may be indirect, when the allelopathic compounds change soil properties, or direct, when these substances interfere in the plant metabolism (FERREIRA and AQÜILA, 2000). The allelochemicals can affect the cellular ultrastructure, concentration and hormonal balance, membrane permeability affecting the uptake of ions, stomatal opening influencing photosynthesis, pigment and protein synthesis, enzyme activity, water relations, sap flow and genetic material (RIZVI and RIZVI, 1992; INDERJIT and CALLAWAY, 2003; INDERJIT et al., 2006).
In this context, allelopathy is responsible for the most varied intraspecific and interspecific interactions in the stabilization and maintenance of different life forms in the environment. Among a great number of species that use this biochemical resource as an advantage to survive in the nature, Kielmeyera coriacea Mart. (Clusiaceae), popularly known as "pau-santo", stands out in Brazilian cerrado because it possesses a class of substances of phytochemical interest called xanthones, besides other substances like xanthonolignoids, aucuparine, steroids, osajaxanthone, triterpenes and biphenyl compounds (CORTEZ et al., 1998).

Considering the ecological and chemical characteristics of $K$. coriacea, the aim of this work was to evaluate the allelopathic potential of the hydroalcoholic extract of its leaves through bioassays of seed germination, seedling growth and mitotic index of Lactuca sativa L.

\section{MATERIAL AND METHODS}

\section{Plant and vegetal extract}

The leaves of $K$. coriacea were collected in the cerrado area from the city of Patos de MinasMG, Brazil $\left(17^{\circ} 30.27^{\prime} 34^{\prime \prime} \mathrm{S}\right.$ and $45^{\circ} 31.21^{\prime} 17^{\prime}$ 'W) in June 2009. The plant was identified and a voucher specimen was deposited in the Mandevilla 
Herbarium at the Centro Universitário de Patos de Minas (UNIPAM) under the number MGHM06327. After collection, the leaves were selected and dried in a forced-air oven at an average temperature of $40^{\circ} \mathrm{C}$ for $24 \mathrm{~h}$, and shortly after, they were ground and the resulting powder was stored in dark plastic bottles.

The hydroalcoholic extract was prepared by mechanical maceration of the powdered plant material in a $70 \%$ ethanol and distilled water solution (at a ratio of 1:10 [w/v]) for $24 \mathrm{~h}$ at room temperature. The extract then was filtered at low pressure under vacuum, a methodology similar to that used by Rutherford and Powrie (1993), Hajhashemi et al. (2003) and Boligon et al. (2009). The extraction was performed in triplicate and the extracts were pooled and concentrated on a rotary evaporator at an average temperature of $60^{\circ} \mathrm{C}$. The resulting extract was lyophilized, and the dried residue was used in the bioassays, according to Aqüila (2000) and Sadraei et al. (2003).

\section{Osmostic potencial teste}

Measurement of the osmotic potential of the extracts was performed using dilutions of polyethylene glycol (PEG-6000) to produce the osmotic potentials of -0.02 to $-1.0 \mathrm{MPa}$, as described by Villela et al. (1991). The measurement of the refractive Brix for each concentration of PEG-6000 and the extract was determined by an ABBE Refractometer and the values were used to calculate the osmotic potential, as described by Bakke et al. (2006).

\section{Germination assay}

The bioassay was conducted in Petri dishes lined with germination paper moistened with $1 \mathrm{~mL}$ of the extract diluted in Tween $80(0.3 \%)$ to concentrations of 5, 10 or $20 \mathrm{mg} \mathrm{mL}^{-1}$. Fifty achenes of Lactuca sativa L. cv. 'Grand Rapids' (lettuce) were sown per dish, separated into experimental and control (Tween 80 0.3\%) groups, and incubated for $48 \mathrm{~h}$ in a growth chamber at $23 \pm 2^{\circ} \mathrm{C}$. The experimental design was completely randomized, with four replicates for each treatment concentration and the control. Germination was monitored every 6 $\mathrm{h}$ and the root protrusion and geotropic curvature was adopted as the evaluation criterion of germination, as described by Ferreira and Aqüila (2000), Maraschin-Silva and Aqüila (2006) and Ferreira et al. (2008). From the data obtained, the following indexes were calculated: germinability or

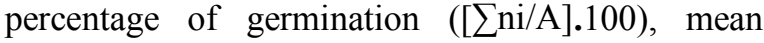
germination time $\left(\mathrm{Tm}=\left[\sum\right.\right.$ ni.ti $] / \sum$ ni $), \quad$ mean germination speed $(\mathrm{Vm}=1 / \mathrm{Tm})$, and the synchronism of germination $\left(E=-\sum\right.$ [fi. $\left.\left.\log 2 . f i\right]\right)$, where $\mathrm{A}=$ total number of achenes put to germinate, $\mathrm{ni}=$ the number of achenes that germinated at each time point ( $\mathrm{ti}$ ), $\mathrm{ti}=$ the time between the beginning of the experiment and the $\mathrm{i}$-th $\mathrm{h}$ of observation and $\mathrm{fi}=$ the relative frequency of germination (LABOURIAU, 1983; SANTANA and RANAL, 2004; PEREIRA et al., 2009).

\section{Viability assay}

The seeds that did not germinate during the germination assay were incubated in a tetrazolium solution (2,3,5-triphenyltetrazolium chloride, $0.5 \%)$ for $6 \mathrm{~h}$ at $30^{\circ} \mathrm{C}$ in the dark, as described by Delouche et al. (1976) and the Rules for Seed Analysis (BRASIL, 2009). The viability (dead or dormant seeds) was determined in order to characterize the metabolic state of the ungerminated seeds (SOUZA, 1996; PINHEIRO and BORGHETTI, 2003).

\section{Seedling growth assay}

In the growth bioassay, twenty-five $L$. sativa seedlings (primary root with approximately $2 \mathrm{~mm}$ ) were placed in the Petri dishes moistened with $1 \mathrm{~mL}$ of the extract $\left(5,10\right.$ or $\left.20 \mathrm{mg} \mathrm{mL}^{-1}\right)$ or Tween 80 solution, as described above. The dishes were placed in a BOD-type growth chamber under the same conditions of the germination assay, as described by Maraschin-Silva and Aqüila (2006) and Ferreira et al. (2008). The experimental design was completely randomized with four replicates for each treatment concentration and the control. After 24 and $48 \mathrm{~h}$ of the beginning of the experiment, the length of the primary roots was measured with a digital caliper.

\section{Mitotic index determination}

For the analysis of the mitotic index, the $L$. sativa achenes were put to germinate and grow in distilled water. After that, the seedlings (primary root with approximately $2 \mathrm{~mm}$ ) were transferred to Petri dishes lined with germination paper moistened with $1 \mathrm{~mL}$ of the extracts at the same concentrations previously described, or Tween 80 solution $(0.3 \%)$. When the roots reached approximately $5 \mathrm{~mm}$, they were collected and prepared by the squash technique (GUERRA and SOUZA, 2002; MAHAJAN and SHARMA, 2008).

First, the roots were fixed in Carnoy's solution (ethanol: glacial acetic acid, 3:1) for $2 \mathrm{~h}$, hydrolyzed in $5 \mathrm{~N} \mathrm{HCl}$ for $15 \mathrm{~min}$ at room temperature, washed with distilled water and stained with $5 \%$ acetic carmine. Cells were observed under a light microscope with $100 x$ magnification. In 
order to verify the number of cells in each phase of the mitosis, 2000 cells were analyzed in each treatment and in the control. The mitotic index (MI) was obtained from the equation, $\mathrm{MI}=(\mathrm{m} / \mathrm{T}) .100$, where $\mathrm{m}=$ the number of cells in mitosis and $\mathrm{T}=$ total number of cells (TABUR and ONEY, 2009).

\section{Phytochemical screening}

Samples (50 g of K. coriacea leaves) were extracted with $250 \mathrm{~mL}$ of water-ethanol (30:70) at $60^{\circ} \mathrm{C}$ (water bath) under magnetic heating agitation for $2 \mathrm{~h}$. The extract solution was filtered and concentrated with a rotary evaporator.

The phytochemical tests were carried out for the above mentioned extract using standard procedures (SIVASANKARI et al., 2010) to identify components such as flavonoids, alkaloids, terpenoids, triterpenoids, hydrolysable tannins, condensed tannins, coumarins, saponins, glycosides and phenols.

\section{Statistics}

Statistical analysis was performed using the Shapiro-Wilks Normality Test and Levene's Test for homogeneity. The transformed data showed normality, and the variances were homogeneous; therefore, the data were analyzed by ANOVA and Tukey $(\alpha=0.5)$ parametric tests. These tests were performed using the SISVAR software, according to Santana and Ranal (2004) and Pereira et al. (2009). For the analysis of the mitotic index, the Chi-square Test was performed to identify a positive response between the experimental and control groups, according to the analysis proposed by Ribeiro et al. (2003).

\section{RESULTS}

The three concentrations of the hydroalcoholic extract reduced the germination of $L$. sativa, markedly at the concentration of $20 \mathrm{mg} \mathrm{mL}^{-1}$ (Table 1). The mean germination time was reduced only by the concentrations of 5 and $10 \mathrm{mg} \mathrm{mL}^{-1}$; however these concentrations increased the mean germination speed. The concentration of $20 \mathrm{mg} \mathrm{mL}^{-}$ 1 did not affect these two parameters when compared to the control group (Table 1). In relation to the synchronism of germination, the achenes were affected by the three concentrations of the extract, as the index was reduced (Table 1).

Table 1. Germinability (G), mean germination time (Tm), mean germination speed (Vm), and synchronism of germination (E) of seeds of L. sativa subjected to different concentrations of a hydroalcoholic extract of $K$. coriacea.

\begin{tabular}{ccccc}
\hline Treatment $\left(\mathrm{mg} \mathrm{mL}^{-1}\right)$ & $\mathrm{G} \pm \mathrm{sd}(\%)$ & $\mathrm{Tm} \pm \mathrm{sd}($ hours $)$ & $\mathrm{Vm} \pm \mathrm{sd}\left(\mathrm{seeds} \mathrm{h}^{-1}\right)$ & $\mathrm{E} \pm \mathrm{sd}(\mathrm{bits})$ \\
\hline 5 & $29.00 \pm 4.76 \mathrm{a}$ & $33.21 \pm 1.35 \mathrm{a}$ & $0.030 \pm 0.00 \mathrm{a}$ & $1.481 \pm 0.51 \mathrm{a}$ \\
10 & $28.00 \pm 7.65 \mathrm{a}$ & $33.62 \pm 3.01 \mathrm{a}$ & $0.029 \pm 0.00 \mathrm{a}$ & $0.963 \pm 0.36 \mathrm{~b}$ \\
20 & $3.50 \pm 1.91 \mathrm{~b}$ & $40.00 \pm 6.32 \mathrm{~b}$ & $0.025 \pm 0.00 \mathrm{~b}$ & $0.229 \pm 0.45 \mathrm{c}$ \\
Control Tween 80 & $67.50 \pm 6.19 \mathrm{c}$ & $38.27 \pm 2.80 \mathrm{~b}$ & $0.026 \pm 0.00 \mathrm{~b}$ & $2.084 \pm 0.17 \mathrm{~d}$ \\
\hline
\end{tabular}

Data presented as mean \pm standard deviation; Means sharing the same letter in a column do not differ significantly by Tukey's test ( $\alpha=$ $0.05)$.

The $K$. coriacea leaf extract reduced the root length of L. sativa seedlings in a dosedependent manner after 24 and $48 \mathrm{~h}$ of experimentation. The reduction was greater at the concentration of $20 \mathrm{mg} \mathrm{mL} \mathrm{m}^{-1}$, regardless of the exposition time to the extract (Table 2).

Table 2. Root length of L. sativa seedlings (RL) subjected to different concentrations of a hydroalcoholic extract of $K$. coriacea after 24 and 48 hours of exposure.

\begin{tabular}{ccc}
\hline Treatment $\left(\mathrm{mg} \mathrm{mL}^{-1}\right)$ & \multicolumn{2}{c}{$\mathrm{RL}(\mathrm{mm})$} \\
\hline & $24 \mathrm{~h}$ & $48 \mathrm{~h}$ \\
10 & $4.40 \pm 0.93 \mathrm{a}$ & $4.83 \pm 0.64 \mathrm{a}$ \\
20 & $3.65 \pm 0.32 \mathrm{~b}$ & $3.65 \pm 0.15 \mathrm{~b}$ \\
Control Tween 80 & $5.55 \pm 0.37 \mathrm{c}$ & $2.64 \pm 0.18 \mathrm{c}$ \\
\hline
\end{tabular}

Data presented as mean \pm standard deviation; Means sharing the same letter in a column do not differ significantly by Tukey's test ( $\alpha=$ $0.05)$. 
The physicochemical characterization of the hydroalcoholic extract of $K$. coriacea leaves revealed that the $\mathrm{pH}$ showed little variation and low acidity values (Table 3 ). The values of the osmotic potential showed variation between -0.0054 and $0.0154 \mathrm{MPa}$ (Table 3).

Table 3. The $\mathrm{pH}$ and osmotic potential of a hydroalcoholic extract of $K$. coriacea under different concentrations.

\begin{tabular}{ccc}
\hline Concentration $\left(\mathrm{mg} \mathrm{mL}^{-1}\right)$ & $\mathrm{pH}$ & Osmotic potential $(\mathrm{MPa})$ \\
\hline 5 & 6.43 & -0.0054 \\
10 & 6.57 & -0.0069 \\
20 & 6.61 & -0.0154 \\
Control Tween 80 & 6.65 & -0.0098 \\
\hline
\end{tabular}

The hydroalcoholic extract of $K$. coriacea leaves reduced the mitotic index of meristematic root cells of $L$. sativa in all three concentrations tested. The concentrations of $5(\mathrm{MI}=14.5)$ and 20 $\mathrm{mg} \mathrm{mL}^{-1}(\mathrm{MI}=15.5)$ produced similar results, whereas the concentration of $10 \mathrm{mg} \mathrm{mL}^{-1}(\mathrm{MI}=11.6)$ was the most effective in the reduction of the mitotic index (Figure 1).

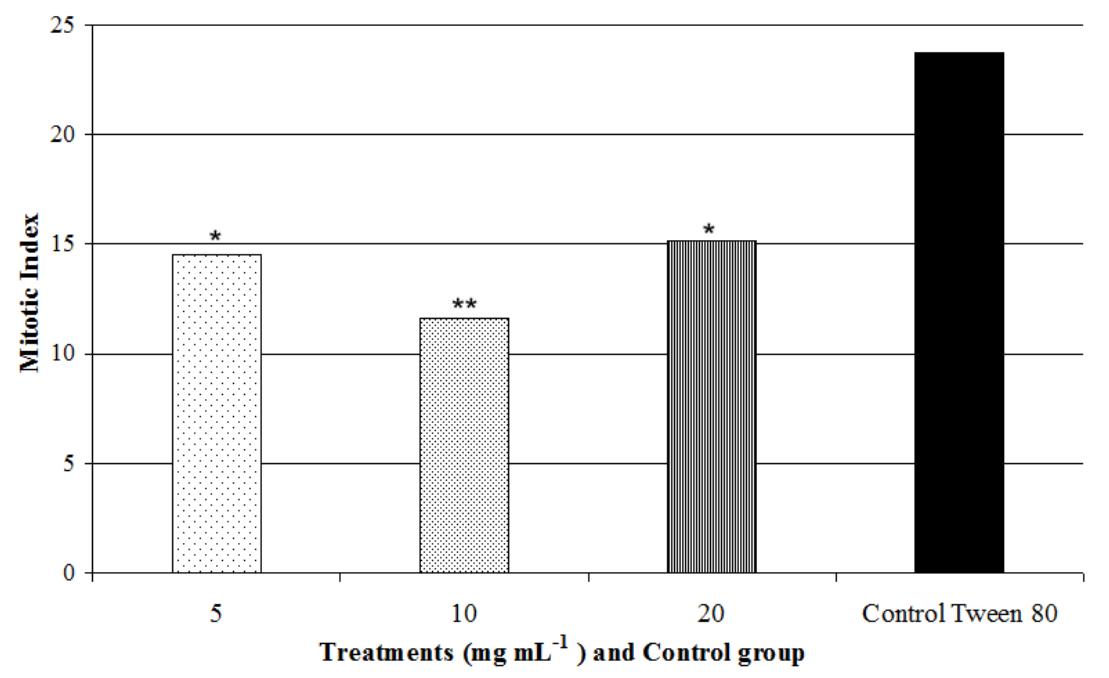

Figure 1. The mitotic index of meristematic cells from $L$. sativa roots treated with different concentrations of an extract of $K$. coriacea or Tween $80(0.3 \%)\left(*\right.$ and $* *$ significant difference, $\left.\chi^{2}<0.01\right)$.

The results of the phytochemical screening showed the presence of triterpenes, coumarins, steroids and flavonoids (Table 4). Triterpenes and steroids were characterized by the less teal and red aspect on the assay tube. Flavonoids showed a less green-orange aspect in the assay, and coumarins a blue fluorescent aspect. More prevalent compounds present in $K$. coriacea hydroalcoholic extract could be attributed to condensed tannins by their heavy teal aspect in the assay. Investigation of anthraquinones, anthocyanines and amino groups was not performed.

Table 4. Results of the phytochemical screening of a hydroalcoholic extract of $K$. coriacea.

\begin{tabular}{llcc} 
& \multicolumn{1}{l}{ Phytochemical Compounds } & Intensity & Color (aspect) \\
\cline { 2 - 4 } & Triterpenes & + & Teal \\
Steroids & ++ & Teal \\
Alkaloids & - & - \\
& Flavonoids & + & Green orange \\
& Coumarins & + & Blue fluorescent \\
& Hydrolysable tannins & - & - \\
Condensed tannins & ++ & Blue green \\
\cline { 2 - 3 }+ low visualization; ++, & moderate visualization; +++, high visualization; -, not visualized
\end{tabular}


Allelochemicals may act in different ways, depending on the environment and life cycle stages, as they reflect different morphological and physiological states. Moreover, the effects can also be variable when considering the plant organ that they are acting upon (AQÜILA et al., 1999; FERREIRA; AQÜILA, 2000).

The germination is not the primary target for allelopathy but the subsequent seedling growth is more susceptible to some allelochemicals, which interfere with nutrient absorption, enzyme activity, water relations, photosynthesis, and respiration (INDERJIT; DAKSHINI, 1995). Therefore, the use of seedlings to seeds is sometimes preferred, which allows the researcher to select uniform seedlings and control their density, making the interpretation of the results easier (WU, 2001).

On the other hand, several researchers have studied the effects of allelochemicals on seed germination based only on the final number of seeds germinated under experimental conditions. The mean germination time, mean germination speed and synchronism of germination are characteristics that express the rate and degree of organization or disorder in chemical reactions that occur with seeds during the germination process and need to be analyzed together with germinability (SANTANA et al., 2006). Therefore, we evaluated all of these indexes besides the root growth to improve the quantification of the germination process when analyzing the effects of allelochemicals.

The tests of pre-emergence demonstrated effect on germinability, mean germination time, mean germination speed and synchronism of germination. The three concentrations of the extract reduced the germinability of $L$. sativa markedly whereas the concentrations of 5 and $10 \mathrm{mg} \mathrm{mL}^{-1}$ decreased the mean germination time and increased the mean germination speed, i.e., the extract interfered with the metabolic reactions that culminate in germination, as seen in the difference between the treatment and the control groups (Table 1).

The importance of germination inhibition by secondary plant metabolites is related to the search for eco-friendly herbicides (VYVYAN, 2002). The influence on germination speed has an ecological significance, because plants that germinate faster can establish in the environment taking advantage of the environmental conditions favorable to the development of new individuals (BORGHETTI and FERREIRA, 2004). On the other hand, plants that germinate more slowly may present a reduced size and, thus, may be more susceptible to stresses and have less chance in the competition for resources (JEFFERSON; PENNACHIO, 2005).

Regarding the synchronism of germination, the index interpretation is: the lower the value of $\mathrm{E}$, the more synchronized is the germination, regardless of the total number of seeds that germinated (SANTANA; RANAL, 2004). In this work, as the extract concentration increased, the germination became more synchronized. The strategy to synchronize the germination process, as well as to reduce the mean germination time, is related to the fast colonization of the environment. On the other hand, the delay and the lower synchronism of germination may increase the chances that at least some seeds can germinate under favorable conditions for seedling establishment (BORGHETTI; FERREIRA, 2004).

The root growth was reduced by the three concentrations of the extract (Table 2). According to Rice (1984) and Aqüila et al. (1999), the uptake of ions and water by the roots is of great importance for the plant growth and development, and they have shown many types of allelopathic effects in this process. Studies conducted by Balke (1985) have shown that flavonoids found in plant extracts have inhibitory activity of root plasma membrane ATPases, while phenolic compounds in excised roots inhibited the uptake of minerals through changes in membrane permeability.

According to Rodrigues et al. (1992) and Ferreira and Borghetti (2004), allelochemicals are inhibitors of germination and development, because they interfere in the cell division, membrane permeability and activation of enzymes. In the present study, the inhibition of L. sativa seed germination and root growth was the consequence of inhibition of cell division (Figure 1). Souza et al. (2005) and Iganci et al. (2006) also found interference in the mitosis caused by the action of plant extracts.

Table 3 shows the values of $\mathrm{pH}$ and osmotic potential of the extract of $K$. coriacea. Experiments performed by Ferreira and Aqüila (2000) and Carmo et al. (2007) demonstrated that these physicochemical characteristics are key factors when the constitution of sugars, amino acids, organic acids, ions and other molecules contained in plant extracts are unknown. Extreme values of $\mathrm{pH}$ and osmotic potential can act on seeds and seedlings masking the allelopathic effect. Lactuca sativa has a wide $\mathrm{pH}$ range for germination that goes from 3.0 to 7.0 (BASKIN; BASKIN, 1998), and therefore, the $\mathrm{pH}$ of the $K$. coriacea extract was suitable to the germination and growth of the test plant. 
Regarding the osmotic potential, Gatti et al. (2004) recommend that the extracts involved in the germination bioassays not exceed the value of -0.2 $\mathrm{MPa}$, which was found in this study (Table 3 ). In view of that, the possibility of interference of these physicochemical factors on the results can be ruled out, reinforcing the idea that the extract presented a toxic effect on the germination and growth of $L$. sativa.

The results of the viability test (tetrazolium) revealed that the seeds did not germinate, when achenes were submitted to different concentrations of $K$. coriacea extracts, showed to be viable and/or dormant, while the ones of control group were died. These observations are according to the Rules for Seed Analysis (BRASIL, 2009).

The phytochemical analysis showed the presence of triterpenes, coumarins, steroids, flavonoids and condensed tannins, compounds of the secondary metabolism (Table 4). The presence of these substances is an indicative of allelopathic potential according to Inderjit and Dakshini (1995), Inderjit (1996), Borella et al. (2009). Moreover, Rice (1984) have demonstrated the action of secondary metabolites of the same chemical classes found in the extract of $K$. coriacea on growth regulators, being able to reduce the activity of auxin and gibberellins, which can inhibit the growth of target plants. Einhellig (1999) and Vyvyan (2002)
SANTOS, V. H. M. et al

also noted that process and cellular events, such as: mitosis, cellular respiration, photosynthesis and enzymatic activities are affected by several flavonoids, tannins, quinones, coumarins and phenolic acids.

Einhellig (1999) highlights the importance of phytochemical studies on species that have an allelopathic potential, because allelopathy rarely results from the single substance action and allelochemicals generally exert their effects when acting together.

Kielmeyera coriacea has an allelopathic potential as it influences the germination parameters and growth of L. sativa, besides presenting substances previously related as allelochemicals in other species. Thus, this plant can serve as model for ecological studies, allowing better understanding of chemical interactions between plants and for studies of new chemical compounds, especially the germination inhibitors and growth retardants, for use in sustainable agriculture.

\section{ACKNOWLEDGMENTS}

The authors acknowledge biologists Carlos Rogério de Figueiredo and Thiago Augusto de Campos for their help in conducting the experiments and Fundação de Amparo à Pesquisa do Estado de São Paulo (FAPESP) for funding the work.

RESUMO: Kielmeyera coriacea Mart. (Clusiaceae), conhecida popularmente como "pau-santo", é uma árvore típica do cerrado brasileiro, conhecida pelos seus variados metabólitos secundários. $\mathrm{O}$ estudo teve como objetivo determinar o potencial alelopático do extrato hidroalcoólico de folhas de $K$. coriacea por meio dos bioensaios de germinação, crescimento de plântulas e índice mitótico de Lactuca sativa L. (alface). Além disso, foi feito o teste de tetrazólio e uma triagem fitoquímica. As concentrações de extrato causaram alterações nos parâmetros de germinação, no crescimento radicular e no índice mitótico. A triagem fitoquímica mostrou a presença de triterpenos, cumarinas, esteroides, flavonoides e taninos condensados, compostos conhecidos por conferir características alelopáticas sobre outras espécies. Estes dados indicam que $K$. coriacea apresenta potencial alelopático pois o extrato de sua folha interfere na germinação e no crescimento da planta alvo, sem qualquer interferência do pH e do potencial osmótico.

PALAVRAS-CHAVE: Crescimento de Plântulas. Índice Mitótico. Kielmeyera coriácea. Parâmetros de Germinação.

\section{REFERENCES}

AQÜILA, M. E. A. Allelopathics effect of Ilex paraguariensis A. St.-Hil. on germination and seedlings growth of Lactuca saliva L. Iheringia Série Botânica, Porto Alegre, v. 53, p. 51-66, 2000.

AQÜILA, M. E. A.; UNGARETTI, J. A. C.; MICHELIN, A. Preliminary observation on allelopathic activity in Achyrocline satureioides (Lam.) DC. Acta Horticulturae, Belgium, v. 502, p. 383-388, 1999. 
BAKKE, IA.; FREIRE, A. L. O.; BAKKE, O. A.; ANDRADE, A. P.; BRUNO, R. L. A. Water and sodium chloride effects on Mimosa Tenuiflora (Willd.) Poiret seed germination. Caatinga, Mossoró, v. 19, n. 3, p. 261267, 2006.

BALKE, N. E. Effects of allelochemicals on mineral uptake and associated physiological process. In: THOMPSON, A. C. (Ed). The Chemistry of Allelopathy. Washington: American Chemical Society, 1985. p.161-178. http://dx.doi.org/10.1021/bk-1985-0268.ch011

BASKIN, C. C.; BASKIN, J. M. Seeds: ecology, biogeography and evolution of dormancy and germination. New York: Academic Press, 1998. 666p.

BOLIGON, A. A.; PEREIRA, R. P.; FELTRIN, A. C.; MACHADO, M. M.; JANOVIK, V.; ROCHA, J. B. T.; ATHAYDE, M. L. Antioxidant activities of flavonol derivatives from the leaves and stem bark of Scutia buxifolia Reiss. Bioresource Technology, New York, v. 100, n. 24, p. 6592-6598, 2009.

http://dx.doi.org/10.1016/j.biortech.2009.03.091

BORELLA, J.; WANDSCHEER, A. C. D.; BONATTI, L. C.; PASTORINI, L.H. Allelopathic effect of aqueous extracts of Persea americana Mill. on Lactuca sativa L. Revista Brasileira Biociências, Porto Alegre, v. 7, n. 3, p. $260-265,2009$.

BORGHETTI, F.; FERREIRA, A. G. Interpretação de resultados de germinação. In: FERREIRA, A. G.; BORGHETTI, F. (Eds). Germinação, do básico ao aplicado. Porto Alegre: Artmed, 2004. p. 209-222.

BRASIL. Regras para análise de sementes. Brasília: Ministério da Agricultura, Pecuária e Abastecimento, 2009. 225-304p.

CARMO, F. M. S.; BORGES, E. E. L.; TAKAKI, M. Allelopathy of Brazilian sassafras (Ocotea odorifera Vell. Rohwer) aqueous extracts. Acta Botanica Brasilica, Feira de Santana, v. 21, n. 3, p. 697-705, 2007.

CORTEZ, D. A. G.; YOUNG, M. C. M.; MARSTON, A.; WOLFENDER, J. L.; HOSTETTMANN, K. Xanthones, triterpenes and a biphenyl from Kielmeyera coriacea. Phytochemistry, New York, v. 47, n. 7, p. 1367-1373, 1998. http://dx.doi.org/10.1016/S0031-9422(97)00731-0

DELOUCHE, J. C.; STILL, T. W.; RASPET, M.; LIENHARD, M. (1976). O teste de tetrazólio para viabilidade da semente. Brasília: AGIPLAN, 1976. 103p.

EINHELLIG, F. A. (1999). An integrated view of allelochemicals amid multiple stresses. In INDERJIT; K. M. M.; DAKSHINI AND C. L. FOY. (Ed). Principles and practices in plant ecology. Boca Raton: CRC Press, 1999. p. 479-494.

FERREIRA, A. G.; AQÜILA, M. E. A. Alellopathy: an emerging topic in ecophysiology. Brazilian Journal of Plant Physiology, Campos dos Goytacazes, v. 12, p. 175-204, 2000.

FERREIRA, A. G.; BORGHETTI, F. (2004). Germinação: do básico ao aplicado. Porto Alegre: Artmed, 2004. 324p.

FERREIRA, N. R.; MEDEIROS, R. B.; SOARES, G. L. Allelopathic potential of capim-annoni-2 (Eragrostis plana Nees) on the seed germination of summer perennial grasses. Revista Brasileira de Sementes, Londrina, v. 30, n. 2 , p. $43-50,2008$.

GATTI, A. B.; PEREZ, S. C. J. G. A.; LIMA, M. I. S. Allelopathic activity of aqueous extracts of Aristolochia esperanzae $\mathrm{O}$. Kuntze in the germination and growth of Lactuca sativa L. and Raphanus sativus L. Acta Botanica Brasilica, Feira de Santana, v. 18, n. 3, p. 459-472, 2004. 
GOTTLIEB, O. R. Micromolecular evolution, systematics and ecology: an essay into a novel botanical discipline. Berlin: Springer-Verlag, 1982. 170p. http://dx.doi.org/10.1007/978-3-642-68641-2

GUERRA, M.; SOUZA, M. J. Como observar cromossomos: um guia de técnica em citogenética vegetal, animal e humana. Ribeirão Preto: Fundação de Pesquisas Científicas, 2002. 131p.

HAJHASHEMI, V.; GHANNADI, A.; SHARIF, B. Anti-inflammatory and analgesic properties of the leaf extracts and essential oil of Lavandula angustifolia Mill. Journal of Ethnopharmacology, Limerick, v. 89, n. 1, p. 67-71, 2003. http://dx.doi.org/10.1016/S0378-8741(03)00234-4

IGANCI, J. R. V.; BOBROWSKI, V. L.; HEIDEN, G.; STEIN, V. C.; ROCHA, B. H. G. Effect of aqueous extracts of the "boldo" species on the germination and mitotic index of Allium cepa L. Arquivos do Instituto Biológico, São Paulo, v. 73, n. 1, p. 79-82, 2006.

INDERJIT. Plant Phenolics in Allelopathy. Botanical Review, Bronx, v. 62, n. 2, p. 186-197, 1996.

INDERJIT, CALLAWAY, R, M, (2003). Experimental designs for the study of allelopathy. Plant and Soil, Crawley, v. 256, n. 1, p. 1-11, 2003.

INDERJIT, CALLAWAY, R. M.; VIVANCO, J. M. Can plant biochemistry contribute to understanding of invasion ecology? Trends in Plant Science, Oxford, v. 11, n. 12, p. 574-580, 2006. http://dx.doi.org/10.1016/j.tplants.2006.10.004

INDERJIT, DAKSHINI, K. M. M. On laboratory bioassays in allelopathy. Botanical Review, Bronx, v. 61, n. 1, p. 28-44, 1995.

INDERJIT, NILSEN, E. T. Bioassays and field studies for allelopathy in terrestrial plants: Progress and problems. Critical Reviews in Plant Sciences, London, v. 22, n. 3, p. 221-238, 2003.

JEFFERSON, L, V.; PENNACHIO, M. Allelopathic effects of foliage extracts from four Chenopodiaceae species on seed germination. Journal of Arid Environments, London, v. 55, n. 2, p. 275-285, 2005. http://dx.doi.org/10.1016/S0140-1963(03)00028-4

LABOURIAU, L. F. G. A germinação das sementes. Washington: Departamento de Assuntos Científicos e Tecnológicos da Secretaria Geral da Organização dos Estados Americano, 1983. 174p.

MAHAJAN, A.; SHARMA, S. Antagonistic effect of polyamines on ABA-induced suppression of mitosis in Allium cepa L. Indian Journal of Experimetal Biology, New Delhi, v. 47, n. 2, p. 136-139, 2008.

MARASCHIN-SILVA, F.; AQÜILA, M. E. A. Contribution to the study of native species allelopathic potential. Revista Árvore, Viçosa, v. 30, n. 4, p. 547-555, 2006.

PEREIRA, R. S.; SANTANA, D. G.; RANAL, M. A. Seedling emergence from newly-collected and storage seeds of Copaifera langsdorffii Desf. (Caesalpinoideae), triângulo mineiro, Brazil. Revista Árvore, Viçosa, v. 33, n. 4, p. 643-652, 2009.

PINHEIRO, F.; BORGHETTI, F. Light and temperature requirements for germination of seeds of Aechmea nudicaulis (L.) Griesebach and Streptocalyx floribundus (Martius ex Schultes F.) Mez (Bromeliaceae). Acta Botanica Brasilica, Feira de Santana, v. 17, n. 1, p. 27-35, 2003.

RIBEIRO, LR.; SALVADORI, D. M. F.; MARQUES, E. K. (2003). Mutagênese Ambiental. Canoas: Ulbra, 2003. 200p.

RICE, E. L. (1984). Allelopathy. 2 edition. Orlando: Academic Press, 1984. 67-68p.

http://dx.doi.org/10.1016/B978-0-08-092539-4.50018-6 
RIZVI, S. G. H.; RIZVI, V. Allelopathy: basic and applied aspects. London: Chapman and Hall, 1992. 480p. http://dx.doi.org/10.1007/978-94-011-2376-1

RODRIGUES, L. R. A.; RODRIGUES, T. J. D.; REIS, R. A. Alelopatia em plantas forrageiras. Jaboticabal: UNESP/FUNEP, 1992. 18p.

RUTHERFORD, M. C.; POWRIE, L. W. Allelochemic control of biomass allocation in interacting shrub species. Journal of Chemical Ecology, New York, v. 19, n. 5, p. 893-906, 1993.

SADRAEI, H.; GHANNADI, A.; MALEKSHAHI. K. (2003). Relaxant effect of essential oil of Melissa officinalis and citral on rat ileum contractions. Fitoterapia, Milano, v. 74, n. 5, p. 445-452, 2003. http://dx.doi.org/10.1016/S0367-326X(03)00109-6

SANTANA, D. G.; RANAL, M. A. Análise da germinação: Um enfoque estatístico. Brasília: UNB, 2004. $247 \mathrm{p}$.

SANTANA, D. G.; RANAL, M. A.; MUSTAFA, P. C. V.; SILVA, R. M. G. Germination measurements to evaluate allelopathic interactions. Allelopathy Journal, Hayana, v. 17, n. 1, p. 43-52, 2006.

SOUZA, F. H. D. Preparo de soluções neutras de tetrazólio. Campo Grande: Embrapa, 1996. 2p.

SOUZA, S. A. M.; STEIN, V. C.; CATTELAN, L. V.; BOBROWSKI, V. L.; ROCHA, B. H. G. Utilização de sementes de alface e de rúcula como ensaios biológicos para avaliação do efeito citotóxico e alelopático de extratos aquosos de plantas medicinais. Revista de Biologia e Ciências da Terra, Paraíba, v. 5, n. 12, p. 3-9, 2005.

SIVASANKARI, K.; JANAKY, S.; SEKAR, T. Evaluation of phytochemicals in select medicinal plants of the Caesalpinia species. Journal of Food Science and Technology, Mysore, v. 3, n. 12, p. 1118-1121, 2010.

TABUR, S.; ONEY, S. Effect of artificial fertilizers on mitotic index and chromosome behaviour in Vicia hybrida L. Journal of Agricultural Research, Lahore, v. 47, n. 1, p. 3-4, 2009.

VILLELA, F. A.; DONI FILHO, L.; SEQUEIRA, E. L. Table of osmotic potential as a function of polyethilene glycol 6000 concentration and temperature. Pesquisa Agropecuária Brasileira, Brasília, v. 26, p. 1957-1968, 1991.

VYVYAN, J. R. Allelochemicals as leads for new herbicides and agrochemicals. Tetrahedron, Oxford, v. 58, n. 9, p. 1631-1646, 2002. http://dx.doi.org/10.1016/S0040-4020(02)00052-2

WU, H.; PRATLEY, J.; LEMERLE, D.; HAIG, T. A. N. M. Screening methods for the evaluation of crop allelopathic potential. Botanical Review, Bronx, v. 67, n. 3, p. 403-415, 2001. 